\title{
EFEKTIVITAS PERDA KOTA SOLOK MENGENAI PENDIRIAN BANGUNAN DALAM PERSPEKTIF HUKUM TATA NEGARA (Studi Kasus di Kelurahan Pasar Pandan Air Mati Kecamatan Tanjung Harapan)
}

\author{
Rahmat Dani Saputra1, Sudi Prayitno² \\ ${ }^{1}$ Institut Agama Islam Negeri (IAIN) BatusangkarFakultas Syariah \\ e-mail: rahmatsaputra131211@gmail.com \\ ${ }^{2}$ Advokat Sudi Prayitno Padang
}

\begin{abstract}
The main problem in this study is the effectiiveness of Solok City regional regulations regarding building construction. The purpose of this discussion is to find out the riles set by the Solok City government regarding building construction and building permit regulations in Solok. City in realizing a beautiful, orderly, simple integrated Solok. City arrangement.
\end{abstract}

Kata kunci: Efektivitas, Perda, Hukum Tata Negara

\section{PENDAHULUAN}

$\mathcal{N}$ egara Indonesia merupakan negara kesatuan yang berbentuk republik. Tujuan $\mathcal{N}$ negara Indonesia berdasarkan pembukaan UUD 1945 alinea ke-4, antara lain memajukan kesejahteraan umum, mencerdaskan kehidupan bangsa, serta menjaga ketertiban dunia. Untuk mencapai tujuan tersebut maka dibentuk pemerintahan baik pemerintahan pusat maupun pemerintahan daerah (UUD 1945 : 1).

Indonesia sebagai negara yang membangun berusaha untuk melakukan pembangunan disegala bidang kehidupan untuk mencapai masyarakat yang sejahtera. Salah satu tujuan pembangunan nasional adalah untuk mewujudkan suatu masyarakat yang adil dan makmur secara merata baik dari materil maupun spiritual, dimana pembangunan nasional merupakan pembangunan manusia Indonesia seutuhnya dan pembangunan masyarakat Indonesia (Ni' matul Huda, 1991 : 91).

Pada dasarnya pembangunan nasional bertujuan untuk mewujudkan masyarakat Indonesia yang adil dan makmur, merata, materil, spiritual melalui peningkatan taraf hidup masyarakat, kecerdasan dan kesejahteraan rakyat.

Mengingat Indonesia sebagai negara dengan wilayah yang luas terdiri dari ribuan pulau dengan budaya, sosial dan kondisi perekonomian yang berbeda antar masingmasing daerah membutuhkan suatu sistem pembangunan daerah yang lebih efektif. Menghadapi kondisi yang demikian maka pemerintah memberikan otonomi pada pemerintah daerah yang dimaksudkan agar daerah tersebut mengatur dan mengurus rumah tangganya sendiri (Syaukani, dkk, $2004: 173$ ).

Sektor pembangunan daerah antara lain meliputi arah pembangunan daerah, peningkatan kerja sama antar daerah dan kemampuan daerah untuk teratur 
melaksanakan pembangunan yang berwawasan lingkungan. Peningkatan peran serta masyarakat dan kemampuan manajemen pembangunan seluruh aparatur pemerintah daerah peningkatan pengembangan desa swadaya dan swakarsa menuju perkotaan yang efesien dan efektif serta penciptaan lingkungan yang sehat, rapi, aman dan nyaman.

Dengan semakin pesatnya pengembangan kota sesuai dengan lajunya pemanfaatan dan penegndalian ruang kota secara terpadu, menyeluruh, efesien dan efektif. Dalam rangka penataan kota yang serasi dan seimbang, untuk terwujudnya kota yang indah, tertib, aman dan nyaman perlu melakukan pengawasan ruang kota secara optimal.

Dalam penyelenggaraan pembangunan fisik berupa bangunan, baik untuk kepentingan umum maupun untuk kepentingan pribadi atau badan, perlu adanya pelayanan, pembinaan, pengaturan, pengawasan dan pengendalian bangunan yang harmonis dan sehat lingkungan. Untuk mewujudkan hal tersebut perlu dibentuknya proses efektifitas dalam mendirikan bangunan. Salah satunya pengawasan mendirikan bangunan.

Salah satu bentuk peraturan daerah yang bersifat mengatur adalah Peraturan Daerah Kota Solok Nomor 04 Tahun 2009 tentang Bangunan Gedung, adapun persyaratan bangunan gedung terdapat pada BAB IV Pasal 8 Umum ialah:

1)Setiap bangunan gedung harus memenuhi persyaratan administratif dan persyaratan teknis sesuai dengan fungsi bangunan gedung.

2)Persyaratan admisnistratif sebagaimana dimaksud dalam ayat (1) meliputi persyaratan status hak atas tanah, status kepemilikan bangunan gedung, dan izin mendirikan bangunan sesuai dengan ketentuan yang berlaku.

3) Persyaratan teknis bangunan gedung sebagai dimana dalam dimaksud ayat (1) meliputi persyaratan tata bangunan dan persyaratan keandalan bangunan gedung.

4)Penggunaan ruang di atas dan atau di bawah tanah dan atau di atas air untuk bangunan harus memiliki izin penggunaan sesuai dengan ketentuan yang berlaku.

5)Persyaratan admistratif dan teknis untuk bangunan gedung adat, bangunan gedung semi permanen, bangunan gedung darurat dan bangunan gedung yang dibangun pada daerah lokasi bencana ditetapkan oleh Walikota sesuai kondisi sosial dan budaya masyarakat Kota Solok.

Dalam Peraturan Daerah Kota Solok Nomor 12 Tahun 2003 tentang Izin Mendirikan Bangunan Bagian Pertama Ketentuan dan Cara Mengajukan PMB pasal 10 ialah untuk mendirikan bangunan dalam Daerah harus mendapat izin dari Kepala daerah.

Peraturan ini merupakan upaya Pemerintah Kota Solok untuk mewujudkan bangunan gedung yang fungsional dan sesuai dengan tata bangunan gedung yang serasi, yang selaras dengan lingkungannya serta memperhatikan nilai-nilai kekeluargaan.

Adanya pelanggaran-pelanggaran dalam melakukan pendirian bangunan sehingga mengganggu fasilitas umum khususnya bagi pejalan kaki. Berdasarkan fenomena di atas mengenai pelanggaran-pelanggaran dalam melakukan pendirian bangunan yang berada di kawasan Kota Solok masih ada yang tidak sesuai dengan Perda Nomor 04 Tahun 2009 tentang Bangunan Gedung dan Perda Nomor 12 Tahun 2003 tentang Izin Bangunan. Hal itu ditentukan oleh gejala-gejala sebagai berikut: 
1. Masyarakat masih kurang paham dalam mengurus atau mengetahui Peraturan Daerah Kota Solok dalam mendirikan izin mendirikan bangunan.

2. Masih banyak masyarakat yang tidak mengetahui jika dalam mendirikan bangunan harus memasang papan izin mendirikan bangunan yang dipasang di area pembangunan.

\section{METODE PENELITIAN}

Jenis penelitian yang penulis gunakan adalah jenis penelitian lapangan (Field Research), untuk mendapatkan data-data dari permasalahan yang diteliti. Teknik pengumpulan data yang penulis gunakan adalah melalui wawancara dan dokumentasi. Pengolahan data dilakukan secara deskriptif kualitatif, kemudian diuraikan serta melakukan klasifikasi terhadap aspek masalah tertentu dan memaparkan melalui kalimat yang efektif.

\section{PEMBAHASAN}

\section{Efektivitas Perda Kota Solok Terhadap Bangunan Yang Ada di Kelurahan Pasar} Pandan Air Mati

Pada Kelurahan Kecamatan Tanjung Harapan ini banyak terjadi pelanggaran mendirikan bangunan.

Adapun kondisi bangunan yang melakukan pelanggaran izin bangunan dapat terlihat saat dalam Peraturan Daerah Nomor 12 Tahun 2003 tentang izin bangunan pasal 36 yang menjelaskan:

a. Setiap pemegang izin mendirikan bangunan wajib memasang papan petunjuk yang bentuk isinya ditetapkan dengan Keputusan Kepala Daerah. Jadi dalam melakukan pembangunan, bangunan yang sedang direnovasi tidak memasang tanda seperti pamflet izin mendirikan bangunan.

b. Kondisi bangunan yang terlalu menjorok kejalan sehingga menyebabkan kemacetan.

c. Bangunan yang sudah berdiri sangat dekat dengan jalan utama sedangkan dalam aturan Perda Nomor 12 Tahun 2003 dalam pasal 1 Nomor 16 menjelaskan bahwa garis batas di tetapkan oleh pejabat yang berwenang yang merupakan batas antara bagian persil yang boleh atau tidak boleh dibangun yang ditarik sejajar dengan jalan, laut, sungai, dan pagar.

\section{Tindak Lanjut dari Pemerintah Kota Solok terhadap Tindakan Masyarakat yang Melanggar Aturan Berdasarkan Peraturan Daerah Kota Solok}

Tindak lanjut dari pemerintah Kota Solok untuk menertibkan bangunan yang melanggar adalah dengan cara menerbitkan surat terguran dari KepalaKelurahan Pasar Pandan Air Mati kepada masyarakat pemilik bangunan yang melanggar Perda Kota Solok sebanyak dua kali. Selanjutnya sampai saat ini tidak ada tindak lanjut oleh pemerintah Kota Solok dalam menertibkan bangunan yang melakukan pelanggaran tersebut. 


\section{Peran Serta Masyarakat terhadap Para Pelanggar yang Melanggar Izin Bangunan Berdasarkan Peraturan Daerah Kota Solok}

Peran serta masyarakat dalam mensosialisasikan pelanggaran terkait pendirian bangunan yaitunya dengan memberitahukan aturan-aturan yang terkait tentang izin bangunan melalui surat edaran pemerintah daerah ataupun memberitahukan langsung dari papan pengumuman yang ada di kantor kelurahan,masjid dan lain-lain serta menanamkan sifat kesadaran antar setiap individu-individu akan pentingnya kenyamanan dan keamanan bersama dalam menggunakan fasilitas umum seperti fasilitas khusus pejalan kaki dan trotoar serta aturan yang telah dibuat pemerintah demi kenyamanan bersama. Tetapi pemberitahuan tersebut kurang terlaksana dengan baik dikarenakan masyarakat kurang peduli terhadap himbauan tersebut. Berdasarkan dari wawancara dengan sekretaris kelurahan pasar pandan air mati Eni Lutriani menjelaskan bahwa:

Pada Kelurahan Pasar Pandan Air Mati ini memang banyak terjadi pelanggaran tentang izin bangunan gedung, itupun disebabkan karena dari Peraturan Pemerintah Daerah tentang Izin Bangunan ini belum berjalan dengan baikterutama pada Kota Solok ini, hal tersebut membuat kami sebagai masyarakat atau penduduk di Kelurahan Pasar Pandan Air Mati merasa terganggu dengan pembangunan yang terlalu memakan bahu jalan. Terutama yang membuat ruang pejalan kaki menjadi sempit dan mobilisasi kendaraan menjadi lambat sehingga menyebabkan kemacetan. Setelah kami melakukan suatu pengawasan terhadap izin mendirikan bangunan di Kelurahan Pasar Pandan Air Mati kami kewalahan dalam menyikapi pelanggaran Peraturan Daerah ini karena disebabkan oleh oknum-oknum tertentu yang menghadang tugas dari masyarakat untuk menyelidiki pelanggaran tersebut, hal inilah menyebabkan Peran Dari Masyarakat belum terlihat begitu berjalan dengan baik dan sesuai dengan prosedur sebagai keamanan pada Kelurahan Pasar Pandan Air Mati (Wawancara dengan Sekretaris Kelurahan Pasar Pandan Air Mati pada Kamis 11 Juni 2020 Pukul 14.29) Lebih lanjutnya disampaikan oleh Doni Alfriadi ketua RT 1 RW2 mengatakan bahwa kondisi Bangunan Gedung yang melakukan pelangggran disebabkan karena ada hambatan dari oknumoknum tertentu yang melindungi pelanggar Peraturan Daerah ini dan masyarakat lebih memilih diam daripada berpartisipasi dalam pencegahan pembangunan- pembangunan tanpa izin. Sebagaimana bapak menjelaskan:

Kelurahan Pasar Pandan Air Mati memang dikategorikan banyak terjadi pelanggaran dalam pembangunan khusunya pada sekitar area pasar, kata Ali Mudar "saya sebagai ketua RT 1 RW 2 sangat meresahkan sekali dengan terjadinya pelanggaran dalam mendirikan bangunan ini, oleh karena itu saya sebagai tokoh masyarakat selalu mencoba dan mengawasi bangunan di kelurahan Pasar Pandan Air mati dengan cara sosialisasi serta dampak yang dirasakan oleh masyarakat terutama bagi pengguna jalan, tetapi dengan sosialisasi tidak dapat mengurangi pelanggaran-pelanggaran yang terjadi". (Wawancara dengan RT 1 RW 2 Ali Mudar pada Kamis 11 Juni 2020 Pukul 16.00)

Tidak berbeda pula dengan apa yang di katakan oleh Sekretatis di Kelurahan Pasar Pandan Air Mati, berdasarkan hasil wawancara yang penulis lakukan dengan Ketua Pemuda yaitu Zibun pada Kelurahan Pasar Pandan Air Mati, Bapak mengatakan bahwa, 
faktor-faktor penyebab belum terlaksananya Peraturan Daerah tentang Bangunan Gedung ini disebabkan karena ada hambatan dari oknum-oknum tertentu yang melindungi pelanggaran Peraturan Daerah ini dan masyarakat banyak yang diam saja dan kurang berpartisipasi dalam mencegah pembangunan yang sedang berlangsung pada Kelurahan Pasar Pandan Air Mati sebagaimana bapak menjelaskan : “Memang banyak pelanggaranpelanggaran dalam mendirikan izin bangunan di kelurahan ini, hal ini kurangnya kesadaran masyrakat dalam mendirikan bangunan.Pada Kelurahan Pasar Pandan Air Mati ini yang membuat resah masyarakat ialah adanya mobil-mobil pemilik gedung yang memarkir di trotoar jalan sehingga menimbulkan kemacetan dan ini sangat menggangu pengguna jalan. Hal tersebut tidak berjalan baik atau masih terjadinya pelanggaran tersebut karena kurang ketatnya pengawasan pada Kelurahan Pasar Pandan Air Mati yang di lakukan oleh pemerintah maupun masyarakat itu sendiri" (Wawancara dengan Ketua Pemuda Bapak Zibun pada Jumat 12 Juni 2020 Pukul 13.00).

Sedangkan hasil wawancara yang penulis lakukan dengan Lurah Pasar Pandan Air Mati Ari Handoko, S.Stp, mengatakan bahwa faktor penyebab belum terlaksananya Peraturan Daerah tentang izin mendirikan bangunan gedung disebabkan karena ada hambatan-hambatan dari oknum-oknum tertentu yang melindungi pelanggaran bangunan ini, masyarakat banyak yang diam saja dan kurang berpartisipasi dalam mencegah pembangunan tanpa izin di kelurahan Pasar Pandan Air Mati dan minimnya pemerintah untuk mensosialisasikan Peraturan Daerah tentang izin mendirikan bangunan gedung. Di sekitaran Pasar Pandan Air Mati Kota Solok juga banyak terjadi pelanggaran-pelanggaran lain seperti rumah mewah yang memakan marka jalan, saya selaku tokoh masyarakat menyikapi permasalahan ini dengan cara turun langsung ke lokasi, tapi dengan turun ke lokasi langsung belum memberikan hasil yang bagus karena ada hambatan dari pemilik rumah tersebut seperti rumah selalu terlihat kosong (Wawancara dengan Lurah Ari Handoko, S,Stp pada Jumat 12 Juni 2020 Pukul 15.00).

Berdasarkan hasil wawancara penulis dengan Ketua RW 02 Besral, mengatakan bahwa faktor-faktor penyebab belum terlaksananya Peraturan Daerah tentang izin mendirikan bangunan gedung ini disebabkan karena ada hambatan dari masyaakat yang diam dan tidak mematuhi dalam mencegah pembangunan tanpa izin di kelurahan Pasar Pandan Air Mati . Ketua RW 02 juga mengungkap pembangunan tanpa izin ini disebabkan oleh bangunan yang sudah lama, masih banyaknya masyarakat yang merenovasi ulang bangunan sehingga menyebabkan bangunan tersebut memakan marka jalan, dan juga masih kurang dalam mengetahui aturan dalam Peraturan Daerah tersebut sehingga masyarakat tetap membangun bangunan walaupun itu jelas melanggar(Wawancara dengan Ketua RW 02 Besral pada Sabtu 13 Juni 2020 Pukul 14.00).

Menurut analisis peneliti, mengenai pendirian bangunan di Kota Solok masih belum efektif dijalankan dimana masih adanya pelanggaran-pelanggaran pembangunan yang tidak sesuai dengan perda dari masyarakat serta tidak adanya pengetahuan masyarakat mengenai perda tersebut. Adapun dari pihak pemerintah kurang adanya sosialisasi perda terhadap masyarakat. 


\section{PENUTUP}

Berdasarkan hasil pembahasan dari penelitian yang telah penulis lakukan maka dapat disimpulkan bahwa:

a. Terkait mengenai Peraturan DaerahKota SolokMengenai Pendirian Bangunanmasih terdapat pelanggaran yang terjadi dikarenakan masih adannya masyarakat yang tidak mengetahui mengenai Perda Kota Solok tentang Izin Mendirikan Bangunan maupun Tentang Bangunan Gedung.

b. Tindak lanjut dari pemerintah daerah Kota Solok terhadap tindakan masyarakat yang melanggar adalah dengan menerbitkan atau mengedarkan surat teguran tetapi tidak ada respon dan tanggapan oleh masyarakat dikarenakan kondisi bangunan tersebut sudah berdiri sejak lama, sebelum adannya peraturan yang mengatur serta masyarakat meminta seluruh bangunan lama untuk di hanucurkan pula, serta adannya oknum yang melindungi bangunan tersebut.

c. Peran serta masyarakat dalam mengimplementasikan perda tentang bangunan gedung menanamkan sifat kesadaran antar setiap individu-individu akan pentingnya kenyamanan dan keamanan bersama dalam menggunakan fasilitas umum seperti fasilitas khusus pejalan kaki dan trotoar serta aturan yang telah dibuat pemerintah demi kenyamanan bersama.

\section{DAFTAR PUSTAKA}

Huda, Ni'matul.2009.Hukum Pemerintah Daerah. Bandung: Nusa Media

Peraturan Daerah Kota Solok Nomor 04 Tahun 2009 tentang Bangunan Gedung

Peraturan Daerah Nomor 12 Tahun 2003 tentang Izin Bangunan

Syaukani, dkk. 2007. Otonomi Daerah Dalam Negara Kesatuan. Yogyakarta: Pustaka Pelajar Undang-Undang Dasar 1945 